\title{
Tropical Pyomyositis
}

Piomiosite tropical

René Coulaud', José Carlos Serufo' ${ }^{1}$ and José Roberto Lambertucci' ${ }^{1}$

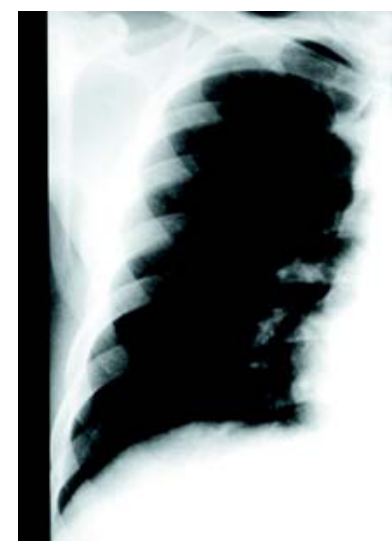

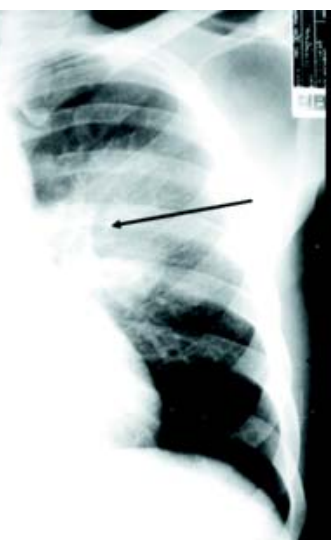

A

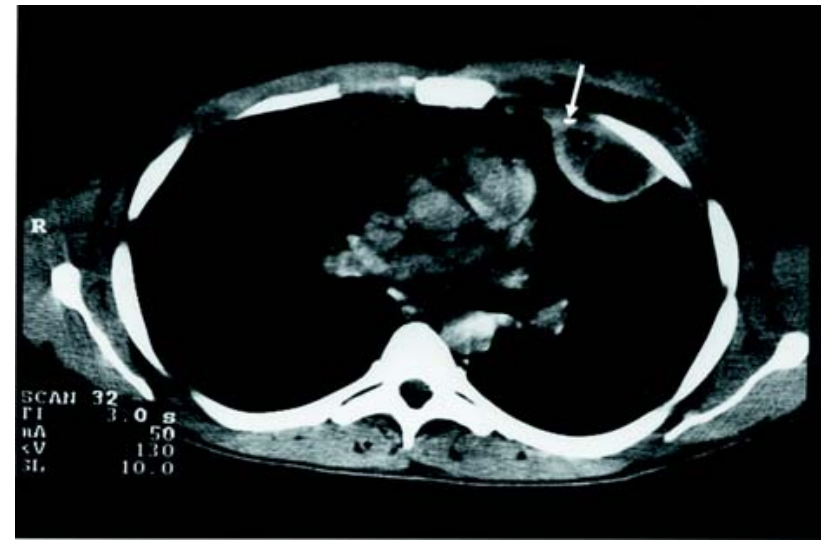

B

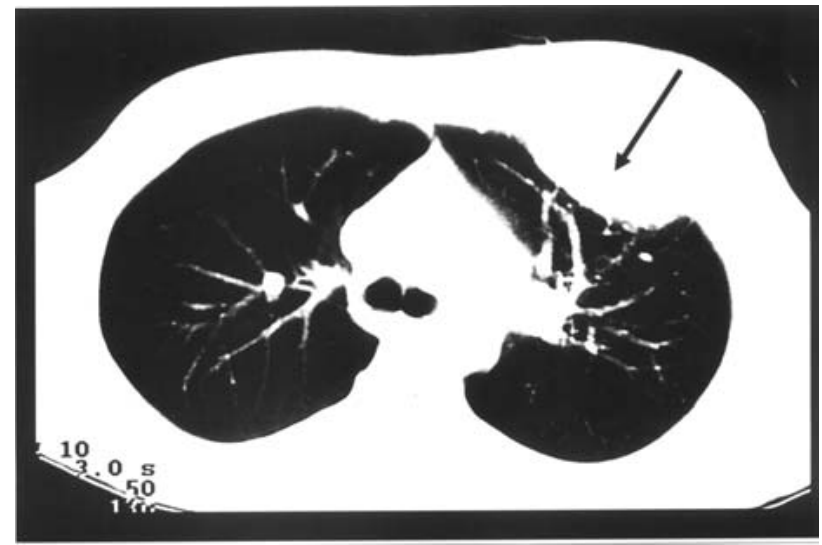

C

1. Serviço de Doenças Infecciosas e Parasitárias do Departamento de Clínica Médica da Faculdade de Medicina da Universidade Federal de Minas Gerais, Belo Horizonte, MG

Adress to: Dr. José Roberto Lambertucci, Depto de Clínica Médica/FM/UFMG. Avenida Alfredo Balena, 190, 30.130-100, Belo Horizonte, MG. Accepted 15 October 2002. 
A 29-year-old, previously healthy man, was admitted to hospital in Belo Horizonte, MG, Brazil, complaining of chest pain and fever for the last two weeks. There was a history of fall with light thoracic trauma three weeks earlier. A routine hemogram revealed leukocytosis with a leftward shift. A plain $\mathrm{x}$ ray of the thorax showed pulmonary condensation with air bronchogram in the left lung. He was treated for pneumonia with ceftriaxone and dismissed after three days. Five days later he returned to our hospital with the same complaints. A second x-ray confirmed previous alterations (Figure A - the black arrow points to the air bronchogram). Computed tomography of the chest though excluded the possibility of pneumonia and disclosed an area of edema affecting mainly the left pectoralis muscle and a mass (abscess) compressing the left lung (Figures $B$ and C). A piece of bone was dislodged (white arrow) suggesting osteomyelitis. Culture of the purulent material drained from the abscess in the muscle during surgery detected Staphylococcus aureus. He was successfully treated with intravenous oxacillin and sent home after 25 days in hospital. He was well when followed-up, at the outpatient clinic, six months later.
O paciente, de 29 anos de idade, foi admitido em hospital de Belo Horizonte, MG, Brasil, relatando dor torácica e febre de início há duas semanas. Ele informava queda e traumatismo torácico leve três semanas antes do início da doença atual. O hemograma revelou a presença de leucocitose com desvio à esquerda. A telerradiografia do tórax mostrou a presença de condensação pulmonar com broncograma aéreo no pulmão esquerdo. Iniciou-se o tratamento da pneumonia com ceftriaxona e o paciente recebeu alta hospitalar melhorado três dias depois. Cinco dias mais tarde ele retornou ao hospital com as mesmas queixas. A segunda radiografia de tórax confirmou as mesmas alterações descritas anteriormente (Figura $A-a$ seta preta chama a atenção para o broncograma aéreo). A tomografia computadorizada do tórax excluiu a presença de pneumonia, mostrou área de edema no músculo peitoral esquerdo e massa comprimindo o pulmão esquerdo (Figuras $\mathrm{B}$ e $\mathrm{C}$ - setas). A seta branca aponta pedaço de osso deslocado pela tumoração e sugere a presença de osteomielite. A cultura da secreção purulenta obtida durante a drenagem cirúrgica do abscesso muscular identificou o Staphylococcus aureus. O paciente foi tratado com oxacilina endovenosa por 25 dias no hospital. No controle em ambulatório, seis meses mais tarde, ele encontrava-se clinicamente bem.

\section{REFERENCES}

1. Rayes AA, Lambertucci JR. The association between human toxocariasis and pyogenic abscesses. Revista da Sociedade Brasileira de Medicina Tropical 32: 425-438, 1999.

2. Rayes AA, Nobre V, Teixeira DM, Serufo JC, Filho GB, Antunes CM, Lambertucci JR. Tropical pyomyositis and human toxocariasis: a clinical and experimental study. American Journal of Medicine 109:422-425, 2000.

3. Soler R, Rodriguez E, Aguilera C, Fernandez R. Magnetic resonance imaging of pyomyositis in 43 cases. European Journal of Radiology 35: 59-64, 2000. 